of the modern theories of atomic and molecular structure. The mathematics is, on the whole, of a standard which is within the capacity of an advanced student of physical chemistry, and the book contains a large amount of well-digested information. References to literature are given.

\section{Annual Reports on the Progress of Chemistry for 1938}

Vol. 35. Pp. xviii +417. (London : Chemical Society, 1939.) 13s. net.

THE present issue of the "Annual Reports on the I Progress of Chemistry", issued by the Chemical Society, contains sections on radioactivity and subatomic phenomena, general and physical chemistry, inorganic chemistry, crystallography, organic chemistry, biochemistry, and analytical chemistry. The plan of dealing with selected topics in somo detail is adopted and the reports are interesting and valuable. Of the 410 pages of text, more than 100 are devoted to organic chemistry. This seems a very high proportion as compared with the other six parts of the book, and those responsible for the reports might well consider whether a better balance is not desirable. Some 50 pages on general and physical chemistry cannot be said to reflect the great importance of this branch of the subject.

\section{Kurzes Lehrbuch der physikalischen Chemie}

Von Prof. Dr. Hermann Ulich. Unter Mitarbcit von Dr. Kurt Cruse. Pp. xvi+315. (Dresden und Leipzig : Theodor Steinkopff, 1938.) 12 gold marks.

7 HE distinguishing features of this book aro the omission of material which belongs specially to physics and the illustration of the theory by numerical examples. A detailed consideration of the laws of thermodynamics, for example, is replaced by a brief but very clear and instructive discussion of the entropy as a measure of internal disorder, and the formulie for maximum work and entropy changes are given in a very practical form. The calculations deal with systems of practical interest and are most instructive and helpful. Although the book is short it is in no way superficial or too elementary, and the emphasis is modern throughout. The brief bio. graphical and historical notes add interest to the text.

Particular care is taken to include English and American work, and the English names of functions, etc., are given. The bibliography is very well chosen, and for those students who can read German the book cannot fail to be helpful and stimulating.

The Chemical Analysis of Foods and Food Products By Dr. Morris B. Jacobs. Pp. xxii +537. (Iondon: Macmillan and Co., Ltd., 1938.) 25s. net.

A GOOD book, full of details which the ordinary A inquirer is not likely to find in the usual text-books. It should be on the shelves of every public analyst, and will bo found of great use for purposes of reference.

\section{ENGINEERING}

Testing Television Sets

Bу J. H. Reyner. Pp. viii $+128+12$ plates. (London : Chapman and Hall, Ltd., 1938.) 9s. 6d. net.

Tr $\mathrm{HE}$ inauguration of a television service in Great Britain has brought forth a number of text. books, not so much on the theory of the subject as on the very practical question of kceping receivers in effective operation. The complexity in a television receiving set might suggest that the liability to failure is high in comparison with normal broadcasting receivers. The fact is, however, that television sets are much better made, and the anticipated massfaulting has not matured. The present text-book gives some indication how faults may be chased and put right, but we should not be doing the book justice if we stopped at that, because in illustrating the way in which the elementary parts might misfunction, the author does give much insight into the working of the soveral parts, so that a technician in a hurry to grasp a formidable subject can get some basic knowledge as well. The text is illustrated with rasters exhibiting typical faults and many clear diagrams.

I. E. C. H.

\section{River Engineering: Principles and Practice}

By F. Johnstone-Taylor. Second edition enlarged. Pp. xxii + 119. (London : Tho Technical Press, Istd., 1938.) 4s. 6d. net.

70 deal with a subject such as river engineering within the limits of a small-sized text-book necessarily involves a considerable degree of com. pression, so that the author has only been able to touch lightly on certain aspects, which might with advantage have been treated at greater length. The explanation of the action of flow at river bends, for example, is rather too superficial to be altogether satisfactory. As a fairly representative outline of the various methods of treatment adopted for the regulation of river channels, the book may serve as a useful introduction to a more detailed study of a difficult science.

B. C.

\section{Medicine}

Recent Advances in Chemotherapy

By Dr. G. M. Findlay. Second edition. Pp. $x+523$. (London: J. and A. Churchill, Itd., 1939.) 21s.

THHE series of books published by Messrs. J. and

A. Churchill dealing with recent advances in the medical sciences has served a useful purpose and been deservedly popular, but they vary much in form. Some of them contain full reviews on selected topics, giving a readable and connected account of certain aspects of the science with which they deal; others tend rather to consist of abstracts of all the papers published on the subject in the last ten years, and give the impression of having been printed directly from a card index. The latter method of writing provides more information per page but less pleasure for the reader. 